\title{
Model Validation of Radiocaesium Transfer from Soil to Leafy Vegetables
}

\author{
P. Sukmabuana and P.I. Tjahaja \\ Nuclear Technology Center for Materials and Radiometry, National Nuclear Energy Agency \\ Jl. Tamansari No. 71, Bandung 40132, Indonesia
}

\section{ARTICLE INFO}

\section{Article history:}

Received 31 March 2010

Received in Revised form 23 April 2012

Accepted 27 April 2012

Keywords:

Radiocaesium,

${ }^{134} \mathrm{Cs}$,

Soil,

Spinach,

Morning glory,

Soil-plant transfer model

\begin{abstract}
A B S T R A C T
The accumulation of radionuclide in plant tissues can be estimated using a mathematical model, however the applicability of the model into field experiment still needs to be evaluated. A model validation has been conducted for radiocaesium transfer from soil to two leafy vegetables generally consumed by Indonesian people, i.e. spinach and morning glory in order to validate the transfer model toward field experimental data. The vegetable plants were grown on the soil contaminated with ${ }^{134} \mathrm{CsNO}_{3}$ of $19 \mathrm{MBq}$ for about 70 days. As the control, vegetables plant were also grown on soil without ${ }^{134} \mathrm{CsNO}_{3}$ contamination. Every 5 days, both of contaminated and un contaminated plants were sampled for 3 persons respectively. The soil media was also tested. The samples were dried by infra red lamp and then the radioactivity was counted using gamma spectrometer. Data of ${ }^{134} \mathrm{Cs}$ radioactivity on soil and plants were substituted into mathematical equation to obtain the coeficient of transfer rate $\left(\boldsymbol{k}_{12}\right)$. The values of $\boldsymbol{k}_{\boldsymbol{1 2}}$ were then used for calculating the ${ }^{134} \mathrm{Cs}$ radioactivity in the vegetable plants. The ${ }^{134} \mathrm{Cs}$ radioactivity in plants obtained from mathematical model analysis was compared with the radioactivity data obtained from the experiment. Correlation of ${ }^{134} \mathrm{Cs}$ radioactivity in vegetables plant obtained from the experiment with those obtained from model analysis was expressed as correlation coefficient, and it was obtained to be 0.90 and 0.71 for spinach and morning glory plants respectively. The values of ${ }^{134} \mathrm{Cs}$ in plants obtained from the model analysis can be corrected using standard deviation values, namely 48.65 and 20 for spinach at $0<\mathrm{t}<55$ days and at $0<\mathrm{t}<78$ days, respectively. Whereas for morning glory the standard deviation value was 0.36 . Although there are differences between ${ }^{134} \mathrm{Cs}$ radioactivity in vegetable plants obtained from model analysis and experiment data, the model of ${ }^{134} \mathrm{Cs}$ transfer from soil to plant can be used for analysing ${ }^{134} \mathrm{Cs}$ radioactivity on leafy vegetable plants grown on radiocesium contaminated soil.
\end{abstract}

(C) 2012 Atom Indonesia. All rights reserved

\section{INTRODUCTION}

After Chernobyl nuclear power plant accident in 1986 and several nuclear weapon tests conducted by many countries, radiocaesium becomes an interesting radionuclide in the environment due to their atmospheric dispersions all over the world and the relatively long half life (30.17 years and 2.05 years for ${ }^{137} \mathrm{Cs}$ and ${ }^{134} \mathrm{Cs}$ respectively). The dispersed radiocaesium can contaminate terrestrial environment and enter the food chain [1-3]. The critical radionuclide pathways from the source point to human is: soil - plant - human, hence for nuclear safety assessment, especially for public dose estimation, the radionuclide transfer from soil to plant is interesting.

\footnotetext{
* Corresponding author.

E-mail address: sukma23@batan.go.id
}

Radiocaesium in contaminated soil will be uptaken by plants through the roots, and accumulated in plants tissues that can be consumed by people. Plants have an ability to accumulate element from the soil, including radionuclide, so the concentration of the element in plants much higher than that in soil. This ability is expressed as bioconcentration factor or transfer factor, which is defined as ratio of element concentration in plant tissue to that in soil medium after equilibrium condition had been reached [3]. The bioconcentration factor is calculated for edible part, i.e. leaves, fruits, or tuber.

Bioconcentration factor can be presented as empirical equation (1).

$$
F_{b}=C_{2} / C_{1}
$$

Where:

$F_{b}$ : bioconcentration factor 
$C_{1}$ : radionuclide concentration in soil $(\mathrm{Bq} / \mathrm{gram})$

$C_{2}$ : radionuclide concentration in tissues $(\mathrm{Bq} / \mathrm{gram})$.

Radiological impact due to radionuclide release to the environment can be evaluated using a mathematical model $[4,5]$. In this model, the radionuclide pathway from release point to human is illustrated as radionuclide transfer among several environmental components, expressed as transfer parameter. Using mathematical model the accumulation of radionuclide in plant tissues can be estimated. To ascertain the mathematical model application of radionuclide from soil to plant transfer, a validation of mathematical model to field or experimental data was conducted. The transfer parameter data of two vegetables plant generally consumed by Indonesian people, i.e. morning glory and spinach, were used in this model validation.

\section{THEORY}

The pathways of radionuclides from the source point until contaminate human body is expressed as radionuclides transfer inter environmental compartments. In soil to plant radionuclide transfer model, soil and plant were assumed as single sub system. The soil is central sub system and the plant is recepient sub system as described in Fig. 1.

In this model, an approximation is taken that during $\mathrm{t}=0$ there is no radionuclide in plant, so the entire radionuclide is in central subsystem. Mathematically, the soil to plant radionuclide transfer and the opposite is formulated by Yasuda [4] and Maltz [6], as below:

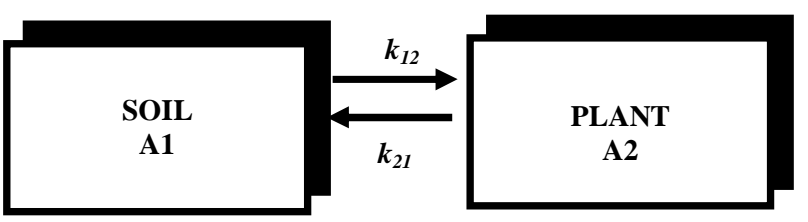

Fig. 1. Compartmental model of soil-plant transfer.

$$
\begin{aligned}
& \frac{d Q_{1}}{d t}=k_{21} Q_{2}-\left(k_{12}+\lambda\right) Q_{1} \\
& \frac{d C}{d t}=\frac{k_{12}}{Y} Q_{1}-\left(k_{21}+\lambda\right) C
\end{aligned}
$$

Where:

$Q_{1}$ : radionuclide concentration in soil $(\mathrm{MBq} /$ mass unit)

$Q_{2}$ : radionuclide concentration in plant $(\mathrm{MBq} /$ mass unit)
$C$ : radionuclide concentration in plant $(\mathrm{MBq} /$ dry weight)

$Y:$ crop production

$\lambda$ : decay constant (1/days)

$\mathrm{k}_{12}$ : transfer rate coefficient of radionuclide transfer from soil to plant (1/days)

$\mathrm{k}_{21}$ : transfer rate coefficient of radionuclide transfer from plant to soil (1/days)

Some literatures reported that there was no radionuclide transfer from plants organ to the soil, so the $k_{21}$ value was equal to zero $[4,7,8]$. The equation (2) and (3) become:

$$
\begin{aligned}
& \frac{d Q_{1}}{d t}=-\left(k_{12}+\lambda\right) Q_{1} \\
& \frac{d C}{d t}=\frac{k_{12}}{Y} Q_{1}-\lambda C
\end{aligned}
$$

The multiplication between radionuclide concentration in soil $\left(Q_{1}\right)$ with soil mass, and also between radionuclide concentration in plant $(C)$ with the dried mass of plants resulting plant radioactivity.

$$
\begin{aligned}
& \frac{d A_{1}}{d t}=-\left(k_{12}+\lambda\right) A_{1} \\
& \frac{d A_{2}}{d t}=k_{12} A_{1}-\lambda A_{2}
\end{aligned}
$$

Where:

$A_{1}=$ radioactivity of soil (MBq)

$A_{2}=$ radioactivity of plant $(\mathrm{MBq})$

The differential equation of (6) and (7) can be solved using analytical method so it was found to be [6],

$$
\begin{aligned}
& A_{1}=A_{1(0)} e^{-\left(k_{12}+\lambda\right) t} \\
& A_{2}=A_{1(0)}\left(e^{-\lambda t}-e^{-\left(k_{12}+\lambda\right) t}\right)
\end{aligned}
$$

\section{EXPERIMENTAL METHODS}

\section{Field experiment}

The soil used in this experiment was clay loam soil from Nuclear Technology Center for Materials and Radiometry (PTNBR) site with the characteristics are as shown in Table 1. The soil was put in the wooden vessel of $1 \times 1 \times 0.30 \mathrm{~m}^{3}$ lined with thick plastic sheet and arranged until $25 \mathrm{~cm}$ height in the vessel. Radiocaesium contamination was carried out by adding ${ }^{134} \mathrm{CsNO}_{3}$ 
solution so the final concentration of ${ }^{134} \mathrm{Cs}$ in the soil medium was about $50-80 \mathrm{~Bq} / \mathrm{g}$.

One hundred vegetable plantlets for each vegetable plants, spinach (Amaranthus spinosus) and morning glory (Ipomoea aquatica), were planted in the contaminated soil and uncontaminated soil as control, respectively, and maintained until about 70 days. Every 5 days three plants were sampled together with the root zone soil. The plant samples were washed and separated into roots, stems, and leave. The plant and soil samples were then dried using infra red lamp until constant weight, gained at about 30 hours. The radioactivity of the dried samples were then measured using gamma spectrometer for 300 seconds and the radioactivity of the ${ }^{134} \mathrm{Cs}$ in the samples were evaluated at the energy of $604.7 \mathrm{keV}$.

Table 1. Soil characteristic used in the experiment

\begin{tabular}{|c|c|c|c|}
\hline No & Parameter & Characteristic & Unity \\
\hline \multicolumn{4}{|c|}{ Macro elements } \\
\hline 1 & $\mathrm{pH}$ & 6.60 & - \\
\hline 2 & $\mathrm{C}$ & 5.67 & $\%$ \\
\hline 3 & $\mathrm{~N}$ & 0.24 & $\%$ \\
\hline 4 & $\mathrm{C} / \mathrm{N}$ & 24.00 & $\%$ \\
\hline 5 & $\mathrm{P}$ & 79.20 & ppm \\
\hline 6 & $\mathrm{~K}$ & 429.00 & ppm \\
\hline 7 & $\mathrm{~N}-\mathrm{NH}_{4}$ & 5.24 & $\mathrm{mg} / 100 \mathrm{~g}$ \\
\hline 8 & $\mathrm{~N}-\mathrm{NO}_{3}$ & 50.19 & $\mathrm{mg} / 100 \mathrm{~g}$ \\
\hline \multicolumn{4}{|c|}{ Exchangeable macro elements } \\
\hline 9 & $\mathrm{Ca}$ & 22.13 & $\mathrm{me} / 100 \mathrm{~g}$ \\
\hline 10 & $\mathrm{Mg}$ & 1.75 & $\mathrm{me} / 100 \mathrm{~g}$ \\
\hline 11 & $\mathrm{~K}$ & 1.38 & $\mathrm{me} / 100 \mathrm{~g}$ \\
\hline 12 & $\mathrm{Na}$ & 0.37 & $\mathrm{me} / 100 \mathrm{~g}$ \\
\hline 13 & KTK & 27.02 & $\mathrm{me} / 100 \mathrm{~g}$ \\
\hline \multicolumn{4}{|c|}{ Micro elements } \\
\hline 14 & $\mathrm{Fe}$ & 5.90 & ppm \\
\hline 15 & $\mathrm{Mn}$ & 6.40 & $\mathrm{ppm}$ \\
\hline 16 & $\mathrm{Cu}$ & 2.40 & ppm \\
\hline 17 & $\mathrm{Zn}$ & 11.50 & ppm \\
\hline 18 & $\mathrm{~S}$ & 35.70 & ppm \\
\hline 19 & $\mathrm{Al}$ & 102.40 & ppm \\
\hline 20 & B & 0.49 & ppm \\
\hline 21 & $\begin{array}{l}\text { Organic } \\
\text { matter }\end{array}$ & 9.75 & $\%$ \\
\hline 22 & $\begin{array}{l}\text { Water } \\
\text { content }\end{array}$ & 29.35 & $\%$ \\
\hline
\end{tabular}

\section{Model validation}

From the field experiment, the ${ }^{134} \mathrm{Cs}$ radioactivity of soil and plant were obtained. Those data were compared with the ${ }^{134} \mathrm{Cs}$ radioactivity of soil obtained from calculation, with the assumption that the radioactivity decrease in soil was attributed by physical decay and plant uptake, such as shown in equation (10).

$$
A_{1}=A_{1(0)} e^{-\lambda t}-A_{2}
$$

Where:

$\boldsymbol{A}_{\boldsymbol{I}}={ }^{134} \mathrm{Cs}$ radioactivity in soil at time ( $\left.\mathrm{t}\right)$

$\boldsymbol{A}_{\boldsymbol{I}(\boldsymbol{\theta})}=$ initial ${ }^{134} \mathrm{Cs}$ radioactivity in soil

$\lambda=$ decay constant $=9,255 \times 10^{-4}$ day $^{-1}$

$\boldsymbol{A}_{2}={ }^{134} \mathrm{Cs}$ radioactivity in plant

The absorption rate of ${ }^{134} \mathrm{Cs}$ from soil to plant $\left(\boldsymbol{k}_{12}\right)$ was determined according to $\boldsymbol{A}_{\boldsymbol{I}}$ and $\boldsymbol{A}_{\boldsymbol{l}(\boldsymbol{\theta})}$ correlation as formulated in equation (8) and (9). The $\boldsymbol{A}_{\boldsymbol{I}(\boldsymbol{\theta})}$ is initial ${ }^{134} \mathrm{Cs}$ radioactivity in soil, whereas the $\boldsymbol{A}_{\boldsymbol{I}}$ is ${ }^{134} \mathrm{Cs}$ radioactivity in soil after (t) days. Based on the experimental results, the $\boldsymbol{k}_{12}$ was determined for two phases, the first is determination of $\boldsymbol{k}_{12}$ using linear function between $\ln \left(\boldsymbol{A}_{1(\boldsymbol{\theta})} / \boldsymbol{A}_{1}\right)$ versus $t$. The $k_{12}$ value is the slope of the linear curve formulated by Birkes, D [9] as below :

$$
k_{12}=\frac{\sum_{i=0}^{t}\left[\left(\ln \frac{A_{1(0)}}{A_{1}}\right)_{i}-\left(\ln \frac{A_{1(0)}}{A_{1}}\right)_{\text {average }}\right] x\left[t-t_{\text {average }}\right]}{\sum_{i=0}^{t}\left[t-t_{\text {average }}\right]^{2}}-\lambda
$$

The $\boldsymbol{k}_{\boldsymbol{1 2}}$ value of the first phase is applied for ${ }^{134} \mathrm{Cs}$ radioactivity in plant when the radioactivity in plant is increase as a time function from $\mathrm{t}=0$ until day of t. For the second phase, the $\boldsymbol{k}_{12}$ value is determined by $\boldsymbol{A}_{\boldsymbol{I}(\boldsymbol{\theta})}$ and $\boldsymbol{A}_{\boldsymbol{I}}$ substitution to equation (12), and applied when the equilibrium condition have been reached. The $\boldsymbol{k}_{12}$ value is an average value from each account formulated as follow (12)

$$
k_{12}=\frac{\ln \frac{A_{1(0)}}{A_{1}}}{t}-\lambda
$$

\section{RESULTS AND DISCUSSION}

The measurement results of ${ }^{134} \mathrm{Cs}$ radioactivity in soil and plant samples were shown in Table 2 and 3 for spinach and morning glory, respectively. Radioactivity of ${ }^{134} \mathrm{Cs}$ in stems and leaves were detected on $15^{\text {th }}$ days after planting for spinach, whereas for morning glory, the ${ }^{134} \mathrm{Cs}$ radioactivity were detected on $5^{\text {th }}$ days in stems and $15^{\text {th }}$ days on leaves. As can be seen in both Table 2 and 3 , the ${ }^{134} \mathrm{Cs}$ radioactivity were decreased in soil with the increase of radioactivity in plant organs until 78 days after planting on contaminated soil. For spinach, the ${ }^{134} \mathrm{Cs}$ radioactivity were increased according to the exposure time until day 55, and after that the radioactivity of plants were decreased, as shown in Fig. 2. For morning glory the ${ }^{134} \mathrm{Cs}$ 
radioactivity in plants organs were fluctuated, but until day 76 (Fig. 3). tend to be increased according to the exposure time

Table 2. The ${ }^{134} \mathrm{Cs}$ radioactivity measured in soil and spinach organs

\begin{tabular}{|c|c|c|c|c|c|}
\hline \multirow[t]{2}{*}{$\begin{array}{l}\text { Times } \\
\text { (days) }\end{array}$} & \multicolumn{2}{|c|}{$\begin{array}{l}{ }^{134} \mathrm{Cs} \text { radioactivity in soil } \\
\left(10^{6} \mathrm{~Bq}\right)\end{array}$} & \multicolumn{3}{|c|}{$\begin{array}{c}{ }^{134} \text { Cs radioactivity in plant organs } \\
(\mathrm{Bq})\end{array}$} \\
\hline & Measurement & Physical decay & Root & Stem & Leaves \\
\hline 0 & 18.525 & 18.525 & & & \\
\hline 5 & 18.335 & 18.441 & & & \\
\hline 9 & 18.350 & 18.373 & & & \\
\hline 14 & 18.194 & 18.289 & & & \\
\hline 19 & 16.218 & 18.175 & & & 0.748 \\
\hline 26 & 15.730 & 17.643 & 0.385 & 0.416 & 10.890 \\
\hline 30 & 15.291 & 17.180 & 5.087 & 3.357 & 13.621 \\
\hline 35 & 13.292 & 14.740 & 16.900 & 25.300 & 41.875 \\
\hline 40 & 13.661 & 13.756 & 19.171 & 27.713 & 47.115 \\
\hline 44 & 12.502 & 12.570 & 27.295 & 33.911 & 55.753 \\
\hline 51 & 9.572 & 10.347 & 28.219 & 58.007 & 83.489 \\
\hline 55 & 7.034 & 7.558 & 38.482 & 78.630 & 117.731 \\
\hline 78 & 7.752 & 8.630 & 33.110 & 73.259 & 95.932 \\
\hline
\end{tabular}

Table 3. The ${ }^{134} \mathrm{Cs}$ radioactivity measured in soil and morning glory organs

\begin{tabular}{|c|c|c|c|c|c|}
\hline \multirow[t]{2}{*}{$\begin{array}{l}\text { Times } \\
\text { (days) }\end{array}$} & \multicolumn{2}{|c|}{$\begin{array}{r}{ }^{134} \text { Cs radioactivity in soil } \\
\left(10^{6} \mathrm{~Bq}\right)\end{array}$} & \multicolumn{3}{|c|}{$\begin{array}{l}{ }^{134} \text { Cs radioactivity in plant organs } \\
(\mathrm{Bq})\end{array}$} \\
\hline & Measurement & Physical decay & Root & Stem & Leaves \\
\hline 0 & 19.200 & 19.200 & 0 & 0 & 0 \\
\hline 5 & 17.609 & 19.104 & 0.398 & 0.485 & 0 \\
\hline 10 & 17.194 & 19.008 & 0.394 & 0.557 & 0 \\
\hline 15 & 15.910 & 18.913 & 1.105 & 0.490 & 0.165 \\
\hline 20 & 15.901 & 18.819 & 0.914 & 1.250 & 0.257 \\
\hline 25 & 16.874 & 18.725 & 1.560 & 0.882 & 0.350 \\
\hline 30 & 16.419 & 18.631 & 2.171 & 0.922 & 0.287 \\
\hline 35 & 16.713 & 18.538 & 1.503 & 0.870 & 0.381 \\
\hline 40 & 16.687 & 18.445 & 1.983 & 5.690 & 1.106 \\
\hline 45 & 14.079 & 18.353 & 2.810 & 2.329 & 0.751 \\
\hline 50 & 15.341 & 18.261 & 2.516 & 1.404 & 0.829 \\
\hline 55 & 16.208 & 18.170 & 3.500 & 5.777 & 0.969 \\
\hline 60 & 16.648 & 18.079 & 1.938 & 1.771 & 0.667 \\
\hline 65 & 16.039 & 17.989 & 3.181 & 2.068 & 1.244 \\
\hline 70 & 15.528 & 17.899 & 1.691 & 3.599 & 1.175 \\
\hline 76 & 15.446 & 17.809 & 4.989 & 3.244 & 1.088 \\
\hline
\end{tabular}

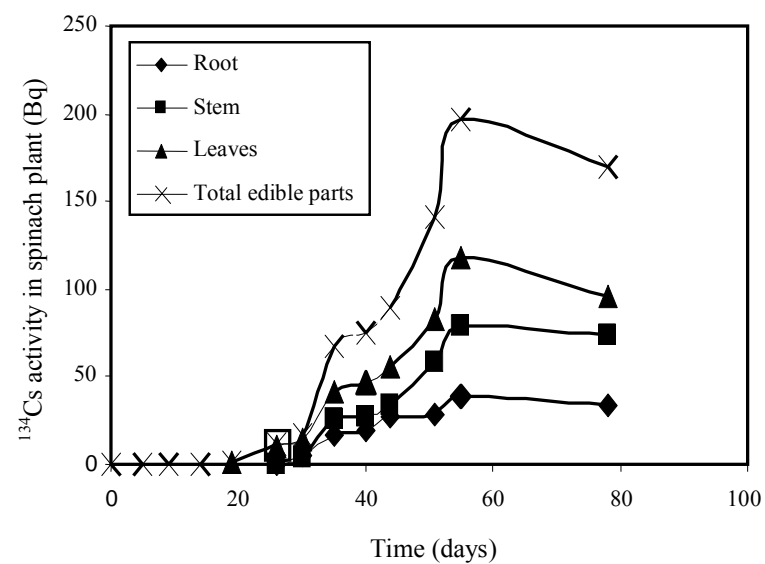

Fig. 2. The ${ }^{134} \mathrm{Cs}$ radioactivity in spinach plant organs as the function of times.

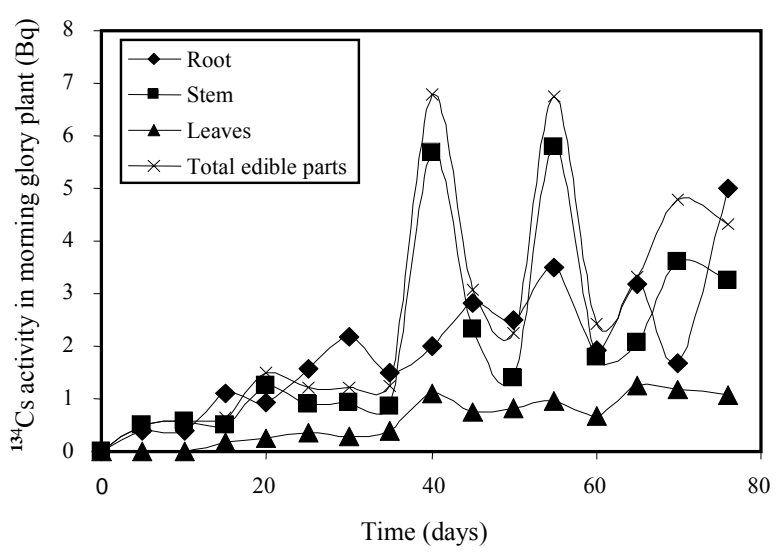

Fig. 3. The ${ }^{134} \mathrm{Cs}$ radioactivity in morning glory plant organs as the function of times. 
Based on Table 2 and Fig. 2, the absorption rate of ${ }^{134} \mathrm{Cs}$ from soil to spinach $\left(\boldsymbol{k}_{12}\right)$ was determined using equation (8-12). For this plant, the $\boldsymbol{k}_{12}$ value of the first phase is applied for the time range of $\mathrm{t}=0$ to $\mathrm{t}=55$ (Fig. 2), whereas the $\boldsymbol{k}_{12}$ value of the second phase was determined for time range of day 55 to day 78 . The calculated $\boldsymbol{k}_{12}$ values of ${ }^{134} \mathrm{Cs}$ transfered from soil to spinach are, $1.82 \times 10^{-5} /$ day for $0<\mathrm{t}<55$ days and $1.26 \times 10^{-5} /$ day for $\mathrm{t}>56$ days. The $\boldsymbol{k}_{12}$ value of ${ }^{134} \mathrm{Cs}$ transfer from soil to morning glory was also calculated for one phase using equation (8-12), and it was obtained to be $9.93 \times 10^{-7} /$ day.

The coefficient of soil to plant transfer rate is varied for each plant species, influenced by metabolism of the plant. Spinach have higher transfer rate than morning glory since each plant species have their own specific physiological characteristic [10]. According to Zhu [10], spinach plant (Amaranthaceae family) is a caesium accumulator.

\section{Model validation}

The validation of the model was carried out to compare the ${ }^{134} \mathrm{Cs}$ accumulation in edible parts of plant (leaves and stems) obtained by experimental measurement with that of mathematical calculation. In the model validation, the $\boldsymbol{k}_{12}$ value obtained by experimental measurement data were substituted to the equation model (9) to calculate the ${ }^{134} \mathrm{Cs}$ radioactivity in the plant. Using the equation (9), the ${ }^{134} \mathrm{Cs}$ radioactivity in plant can be calculated for each sampling time and the calculation results are listed in Table 4 and 5, and plotted in Fig. 4 and 5.

Table 4. The comparison of ${ }^{134} \mathrm{Cs}$ radioactivity in spinach based on experimental data and mathematical model calculation

\begin{tabular}{ccc}
\hline Time (days) & \multicolumn{2}{c}{$\begin{array}{c}\text { The }{ }^{134} \text { Cs radioactivity in edible part } \\
\text { of spinach }(\mathrm{Bq})\end{array}$} \\
\cline { 2 - 3 } & $\begin{array}{c}\text { Experiment } \\
(\mathrm{Bq})\end{array}$ & $\begin{array}{c}\text { Mathematical model } \\
(\mathrm{Bq})\end{array}$ \\
\hline 0 & 0 & 0 \\
5 & 0 & 16.801 \\
9 & 0 & 30.129 \\
14 & 0 & 46.649 \\
19 & 0.748 & 63.014 \\
26 & 11.306 & 85.667 \\
30 & 16.978 & 98.478 \\
35 & 67.175 & 114.356 \\
40 & 74.828 & 130.083 \\
44 & 89.664 & 142.557 \\
51 & 141.496 & 164.159 \\
55 & 196.361 & 176.374 \\
78 & 169.190 & 169.768 \\
\hline
\end{tabular}

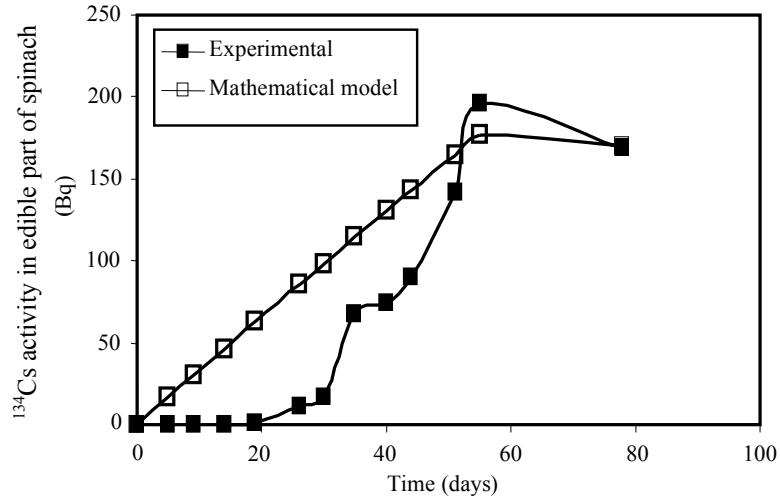

Fig. 4. The ${ }^{134} \mathrm{Cs}$ radioactivity in edible part of spinach planted in soil contaminated with ${ }^{134} \mathrm{Cs}$.

Table 5. The comparison of ${ }^{134} \mathrm{Cs}$ radioactivity in morning glory based on experimental data and mathematical model calculation

\begin{tabular}{ccc}
\hline $\begin{array}{c}\text { Time } \\
(\text { days })\end{array}$ & $\begin{array}{c}\text { The }{ }^{134} \text { Cs radioactivity in edible part of } \\
\text { morning glory }(\mathrm{Bq})\end{array}$ \\
\cline { 2 - 3 } & $\begin{array}{c}\text { Experiment } \\
(\mathrm{Bq})\end{array}$ & $\begin{array}{c}\text { Mathematical model } \\
(\mathrm{Bq})\end{array}$ \\
\hline 0 & 0 & 0 \\
5 & 0.485 & 0.384 \\
10 & 0.557 & 0.764 \\
15 & 0.655 & 1.140 \\
20 & 1.507 & 1.514 \\
25 & 1.232 & 1.883 \\
30 & 1.208 & 2.250 \\
35 & 1.250 & 2.612 \\
40 & 6.796 & 2.972 \\
45 & 3.079 & 3.328 \\
50 & 2.233 & 3.680 \\
55 & 6.746 & 4.030 \\
60 & 2.439 & 4.376 \\
65 & 3.312 & 4.718 \\
70 & 4.774 & 5.058 \\
76 & 4.332 & 5.461 \\
\hline
\end{tabular}

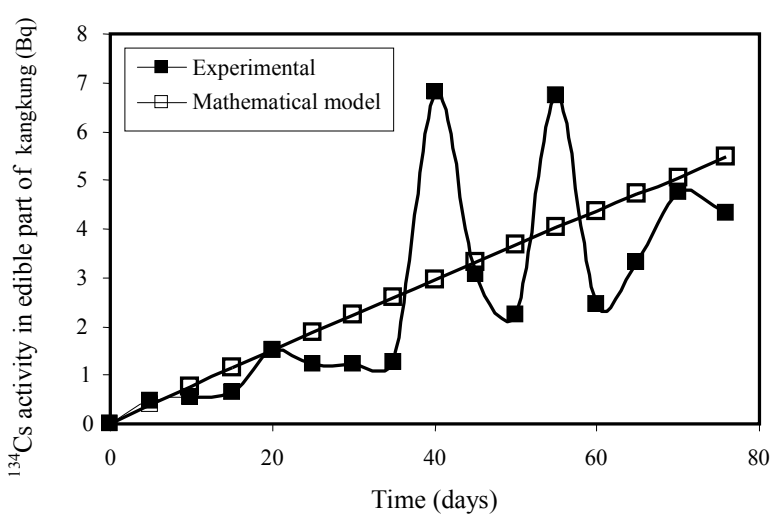

Fig. 5. The ${ }^{134} \mathrm{Cs}$ radioactivity in edible part of morning glory planted in soil contaminated with ${ }^{134} \mathrm{Cs}$.

From the data plot in Fig. 4 and 5 it can be seen that there are differences between experimental 
data compared to the calculation results. In Fig. 4 and 5 the ${ }^{134} \mathrm{Cs}$ radioactivity curves obtained from model analysis shows smooth curve, whereas the ${ }^{134} \mathrm{Cs}$ radioactivity in plant obtained from experimental measurement shows fluctuation phenomenon. However, this fact can be understood since in the mathematical model, the complexity of plant physiology doesn't take into account $[1,4]$. The relationship between the ${ }^{134} \mathrm{Cs}$ radioactivity in plant obtained from experiment and from mathematical calculation is evaluated by correlation coefficient determined using equation (13) [9].

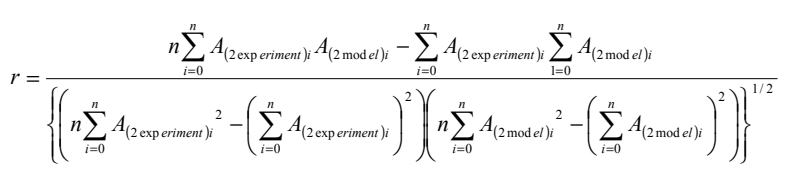

From the calculation using equation (13) it was found correlation coefficient of 0.90 and 0.71 for spinach and morning glory respectively. It means that the 90 percent of spinach data obtained from the model are fit with the data obtained from the experiment, whereas only 71 percents for morning glory data are fit. The deviation of data obtained from model calculation can be corrected by calculating the deviation standard, expressed as equation (14) [9].

$$
S D=\left[\frac{\sum_{i=1}^{n}\left(A_{2 \operatorname{model}(i)}-A_{2 \operatorname{experiment}(i)}\right)^{2}}{n-1}\right]^{1 / 2}
$$

For spinach it was found the deviation standard of 48.65 for $0<\mathrm{t}<55$ days and 20 for $56<\mathrm{t}<78$ days, whereas for morning glory the deviation standard obtained is 0.36 . The deviation standard values obtained from the calculation are substituted to the mathematical equation as shown in equation (15).

$$
A_{2}=A_{1(0)}\left(e^{-\lambda t}-e^{-\left(k_{12}+\lambda\right) t}\right) \pm S D
$$

The mathematical model of ${ }^{134} \mathrm{Cs}$ transfer from soil to spinach plant is as shown in equation (16) and (17).

$$
\begin{aligned}
& A_{2}=A_{1(0)}\left(e^{-\left(9.25527 \times 10^{-4}\right) t}-e^{-\left(0.7345 \times 10^{-4}\right)}\right) \pm 48.65, \text { for } 0 \leq \mathrm{t} \leq 55 \\
& A_{2}=A_{1(0)}\left(e^{-\left(0.25527 \times 10^{-4}\right) t}-e^{-\left(0.67862 \times 10^{-4}\right)}\right) \pm 20.00, \text { for } \mathrm{t}>56
\end{aligned}
$$

The mathematical model of ${ }^{134} \mathrm{Cs}$ transfer from soil to morning glory is as shown in equation (18).

$$
A_{2}=A_{1(0)}\left(e^{-\left(0.25527 \times 10^{-4}\right) t}-e^{-\left(0.56 \times 10^{-4}\right) t}\right) \pm 0.36
$$

\section{CONCLUSSION}

The mathematical model of ${ }^{134} \mathrm{Cs}$ transfer from soil to vegetables plant had been applied for experimental data. Based on the decrease of ${ }^{134} \mathrm{Cs}$ concentration in soil as time function due to physical decay and plant uptake, the transfer rate coefficient can be determined. The $k_{12}$ values of ${ }^{134} \mathrm{Cs}$ soil to spinach obtained from this experimental data calculation are $1.82 \times 10^{-5} /$ day for $0<\mathrm{t}<55$ days and $1.26 \times 10^{-5} /$ day for $\mathrm{t}>56$ days. For morning glory, the $k_{12}$ value is lower than that of $k_{12}$ for spinach plant, i.e. $9.93 \times 10^{-7} /$ day.

From the model validation of ${ }^{134} \mathrm{Cs}$ from soil to vegetables crop it was obtained that there are differences between model calculations with that of measurement. The correlation between the model calculations with the experimental measurement is expressed as correlation coefficient. For spinach the correlation coefficient obtained is 0.90 whereas for the morning glory is 0.71 . The deviations of the model from the experimental data are corrected by deviation standard substitution. The model equations for spinach are:

$$
\begin{aligned}
& A_{2}=A_{1(0)}\left(e^{-\left(9.25527 \times 10^{-4}\right) t}-e^{-\left(9.7345 \times 10^{-4}\right) t}\right) \pm 48.65 \text { at } 0<\mathrm{t}<55 \\
& A_{2}=A_{1(0)}\left(e^{-\left(9.25527 \times 10^{-4}\right) t}-e^{-\left(9.67862 \times 10^{-4}\right) t}\right) \pm 20.00 \text { at } 55<\mathrm{t}<78
\end{aligned}
$$

For morning glory the model equation becomes:

$$
A_{2}=A_{1(0)}\left(e^{-\left(9.25527 \times 10^{-4}\right) t}-e^{-\left(9.56 \times 10^{-4}\right) t}\right) \pm 0.36
$$

\section{REFERENCES}

1. N.V. Goncharnova, Global NEST Journal 11 (2009) 260.

2. S. Uchida and K. Tagami, J. Radioanal. Nucl. Chem. 273 (2007) 205.

3. Y.H. Choi, K.M. Lim, I. Jun, D.W. Park, D.K. Keum, and, C.W. Lee, J. Environ. Radio. 100 (2009) 746.

4. H. Yasuda, J. Nucl. Scien. Tech. 32 (1995) 1272.

5. S.I. Spiridonov, S.V. Fesenko and Sanzharova, Radioprotection, Suppl 1, 40 (2005) s119.

6. J. Maltz, Compartmental Modelling. http: //www.berkeley.edu (cited 2008).

7. H.J.M. Bowen, Environmental Chemistry of The Elements, Academic Press, London, NY (1979).

8. M. Greger, Uptake of Nuclide by Plants, 
Technical report TR-04-14, Swedish Nuclear Fuel and Waste Management Co., Stockholm (2004).

9. D. Birkes and Y. Dodge, Alternative Method of
Regression, John Wiley and Sons, Inc, New York, USA (1993).

10. Y.G. Zhu and E. Smolders, J. Exper. Botany 51 (2000) 1635. 